Bull. Chem. Soc. Ethiop. 2017, 31(2), 211-222.

ISSN 1011-3924

(C) 2017 Chemical Society of Ethiopia and The Authors

Printed in Ethiopia

DOI: http://dx.doi.org/10.4314/bcse.v31i2.3

\title{
CHEMICAL COMPOSITION OF CLINOPODIUM MENTHIFOLIUM AQUEOUS EXTRACT AND ITS INFLUENCE ON ANTIOXIDANT SYSTEM IN BLACK NIGHTSHADE (SOLANUM NIGRUM) AND PEPPER (CAPSICUM ANNUUM) SEEDLINGS AND MORTALITY RATE OF WHITEFLY (TRIALEURODES VAPORARIORUM) ADULTS
}

\author{
Jovana Šućur ${ }^{1 *}$, Aleksandra Popović ${ }^{1}$, Miloš Petrović ${ }^{1}$, Vojislava Bursić ${ }^{1}$, Goran Anačkov², \\ Dejan Prvulović ${ }^{1}$ and Đorđe Malenčić ${ }^{1}$ \\ ${ }^{1}$ University of Novi Sad, Faculty of Agriculture, Trg Dositeja Obradovića 8, Novi Sad, Serbia \\ ${ }^{2}$ University of Novi Sad, Faculty of Science, Trg Dositeja Obradovića 8, Novi Sad, Serbia
}

(Received December 22, 2016; revised September 12, 2017)

\begin{abstract}
The use of allelochemicals as weed control agents is becoming widely investigated. However, the impact of these bioherbicides on cultivated plants is less known. This study was carried out in order to evaluate the allelopathic effects of the aqueous extract of Clinopodium menthifolium on black nightshade (Solanum nigrum) antioxidant properties to explore the potential of this species in weed control and on pepper (Capsicum annuum) antioxidant properties so as to assess its possible side effects when applied as bioherbicide in organic production. Taking into account that plant extracts should be an alternative source for insect control, additional aim was also to evaluate contact effect of $C$. menthifolium aqueous extract against the greenhouse whitefly (Trialeurodes vaporariorum). Analysis by HPLC confirmed the presence of gallic acid, caffeic acid and 2-hidroxy-cinnamic acid as major components in the $C$. menthifolium aqueous extract. Both tested concentrations of $C$. menthifolium aqueous extract induced lipid peroxidation in black nightshade leaves and roots. It was observed that the aqueous extract with a concentration of $0.1 \%$ showed a toxic effect with $50 \%$ mortality of greenhouse whitefly adults.
\end{abstract}

KEY WORDS: Allelochemicals, Antioxidants, Biopesticides, Capsicum annuum, Clinopodium menthifolium, Solanum nigrum, Trialeurodes vaporariorum

\section{INTRODUCTION}

The most adopted method for controlling weeds and insect pests is the application of pesticides [1]. Plants' phenolic compounds can offer an alternative method to the chemical control of pathogens on agricultural crops and reduce the use of synthetic herbicides reducing environmental pollution [2]. Allelopathy is an interference mechanism in which live or dead plant materials release allelochemicals, which inhibit or stimulate the associated plant growth [3]. Allelochemicals are usually biomolecules produced in plant secondary metabolismor side products of main metabolic pathways [4]. Most of them originate from the shikimic acid and the acetate pathway [5]. Allelochemicals may be present in all plant organs like leaves, stems, flowers, fruits, seeds and roots [1]. The delivery of allelochemicals into the environment is often thought leaching from aerial plant parts, through volatile emissions, by root exudation and decomposition of plant residues [6]. Released allelochemicals into the atmosphere or rhizosphere in ample quantities and long persistence can affect a neighboring plant [3]. The most common inhibitor effects are visible upon such plant functions as respiration, water balance, stomatal function and inhibition of photosynthesis [7]. One of the main invisible effects of allelochemicals on the target plant is uncontrolled production and accumulation of reactive oxygen species (ROS) such as superoxide anions $\left(\mathrm{O}_{2}{ }^{-}\right)$, hydroxyl $(\mathrm{OH})$ or hydroperoxyl $\left(\mathrm{HO}_{2}{ }^{-}\right)$ radicals [8]. ROS are natural products of plant metabolism, but under stress conditions, their generation is greatly increased [9]. These free radicals can react with lipids in cell membranes, proteins in tissues, carbohydrates and DNA [10].

*Corresponding author. E-mail: jovana.sucur@polj.edu.rs

This work is licensed under the Creative Commons Attribution 4.0 International License 
Excessive production of ROS is accompanied by the activation of the cellular antioxidant system [11]. It includes enzymatic defenses, such as catalase (CAT), superoxide dismutase (SOD) and peroxidases, which metabolize superoxide anions and hydrogen peroxide, preventing most of the formation of the toxic hydroxyl radicals ( $\mathrm{OH})$ [10]. On the other hand, the cellular level of $\mathrm{H}_{2} \mathrm{O}_{2}$ could be toxic enough to inhibit the enzymes' activity, leaving the plant vulnerable to oxidative damage [12]. Thus, allelochemicals present in plants can be used in weeds control. For this purpose, more suitable are aqueous extract of plants because of easier application in crops. One of highly resistant weed species in our crops, especially in soybean, potato and pepper crops, is black nightshade. In soybean crops, the presence of this weed leads to loss in yield if it grabs with soybean because its seeds are similar to soybean and affects the quality of the soybean seeds.

This study was carried out in order to evaluate the allelopathic effects of the aqueous extract of Clinopodium menthifoliumon black nightshade (Solanum nigrum) antioxidant properties to explore the potential of this species in weed control and on pepper (Capsicum annuum) antioxidant properties so as to assess its possible side effects when applied as bioherbicide in organic production. The effect of two concentrations $(0.1$ and $0.2 \%)$ of $C$. menthifolium aqueous extract on lipid peroxidation process, as well as the activity of antioxidant enzymes (catalase (CAT), superoxide dismutase (SOD) and peroxidase (POD)) in leaves and roots of black nightshade and pepper seedlings was examined 24, 72 and $120 \mathrm{~h}$ after the treatment. The third aim was to evaluate effectiveness of $C$. menthifolium aqueous extract against the greenhouse whitefly (Trialeurodes vaporariorum). Whitefly is a major problem in our greenhouses, especially in heated greenhouses where this pest has good conditions for development during the whole year. Also, their biology and large number of generation are cause of heavy control. Furthermore, the chemical composition of the aqueous extract used was achieved by HPLC, and total phenolic and flavonoid content were determined.

\section{EXPERIMENTAL}

\section{Chemicals and reagents}

All the chemicals and reagents used in this study were of analytical grade reagents with highest purity. These chemicals and reagents were: ferulic acid, trans-cinnamic acid, gallic acid, caffeic acid, 2-hydroxycinamic acid, p-coumaric acid, chlorogenic acid, quercetin, kaempferol, (+)catechin hydrate, cyanin chloride, idaenin chloride, callistephin chloride and kuromanin chloride, rutin, Folin-Ciocalteu reagent, L-methionine,nitrotetrazolium blue chloride (NBT), riboflavin and thiobarbituric acid (Sigma Aldrich); guaiacol (Merck, Darmstadt); pyrogallol and aluminum chloride hexahydrate (Alfa Aesar, United States); potassium phosphate monobasic, ethylenediaminetetraacetic acidand hydrogen peroxide (Zorka pharma, Serbia); sodium carbonate, magnesium sulfate heptahydrate, calcium nitrate tetrahydrate, potassium nitrate, trichloroacetic acid (Centrohem, Serbia).

\section{Plant material and preparation of the aqueous extract}

The wild, aromatic plant, Clinopodium menthifolium (Host) was collected at localities near the Adriatic coast in Montenegro, around Sutomore and Čanj city (longitude: 19 $00^{\prime} 30.10^{\prime \prime} \mathrm{E}$, latitude: $42^{\circ} 09^{\prime} 52.19^{\prime}$ ' N, altitude: $31 \mathrm{~m}$ ), in May of 2012. Voucher specimen of collected plant was confirmed and deposited at the Herbarium of The Department of Biology and Ecology, Faculty of Science, University of Novi Sad, with the identification number 2-1543.

The aqueous extract of $C$. menthifolium was prepared with air-dried plant material spilled with boiling distilled water $(10 \%$, w/v) and left for $24 \mathrm{~h}$. After $24 \mathrm{~h}$, the extract was filtered through Whatman No. 4 filter paper and kept at $4{ }^{\circ} \mathrm{C}$ in the fridge until application. 


\section{Determination of total phenolic and flavonoid contents}

The total phenolic content of the $C$. menthifolium aqueous extract was determined according to the Folin-Ciocalteu method [13]. Extract $(20 \mu \mathrm{L})$ was mixed with $3.4 \mathrm{~mL}$ of deionized water, $0.4 \mathrm{~mL}$ of $20 \%$ sodium carbonate and $0.2 \mathrm{~mL}$ of Folin-Ciocalteu reagent, which was previously diluted (1:2) with distilled water. After incubation at room temperature for $30 \mathrm{~min}$, the absorbance of the reaction mixture was measured at $720 \mathrm{~nm}$ using an UV/VIS spectrophotometer (Thermo Scientific Evolution 220, USA). The total phenolic content was determined using a standard curve with gallic acid $(0.1-2.0 \mathrm{mg} / \mathrm{mL})$. The data were expressed in $\mathrm{mg}$ of gallic acid equivalents per gram of dry weight ( $\mathrm{mg} \mathrm{GAE} / \mathrm{g}$ of DW).

The total flavonoids were estimated according to the method described by Markham [14]. Extract $(0.4 \mathrm{~mL})$ was mixed with $1 \mathrm{~mL}$ of deionized water and $2.5 \mathrm{~mL}$ of $2 \%$ aluminium chloride hexahydrate solution. After incubation at room temperature for $15 \mathrm{~min}$, the absorbance of the reaction mixture was measured at $430 \mathrm{~nm}$ using an UV/VIS spectrophotometer (Thermo Scientific Evolution 220, USA). The total flavonoid content was determined using a standard curve with rutin $(1.0-50.0 \mathrm{mg} / \mathrm{mL})$. The data were expressed in $\mathrm{mg}$ of rutin equivalents per gramof dry weight (mg rutin/g of DW).

\section{Chemicals and apparatus}

All solvents used were of chromatography grade and were obtained from J. T. Baker (Deventer, The Netherlands). Ferulic acid (99.0\%), trans-cinnamic acid $(99.0 \%)$, gallic acid $(99.9 \%)$, caffeic acid (98.0\%), 2-hydroxycinamic acid $(97.0 \%)$, p-coumaric acid $(98.0 \%)$, chlorogenic acid $(95.0 \%)$, quercetin $(98.0 \%)$,kaempferol $(97.0 \%)$, $(+)$-catechin hydrate $(98.0 \%)$, cyanin chloride $(96.5 \%)$, idaenin chloride $(98.0 \%)$, callistephin chloride $(97.0 \%)$ and kuromanin chloride $(98.0 \%)$ were used as analytical standards. The stock standard solutions were prepared by dissolving the required analytical standard in methanol, while the working solution, i.e., the mixture of the studied phenol compounds, was obtained by mixing and diluting the stock standards with mobile phase, resulting in a final mass concentration of $100 \mu \mathrm{g} / \mathrm{mL}$. The composite mixtures of all phenol compounds at appropriate concentrations were used to spike samples in the data validation settings. Acetic acid was of p.a. grade (Carl Roth).

\section{Determination of phenolic compounds}

HPLC analysis. The chromatographic separation for phenolic compounds was achieved using an Agilent 1100 (Agilent Technologies, USA) HPLC system with a binary pump and diode array detector-DAD. The phenolic acids were separated on a ZORBAX SB-Aq ( $5 \mu \mathrm{m}$ particle size: $4.6 \times 250 \mathrm{~mm}$, Agilent) column and the other phenolic compounds on a ZORBAX SB-C18 (5 $\mu \mathrm{m}$ particle size: $3.0 \times 250 \mathrm{~mm}$, Agilent) column. The aqueous extract was filtered through $0.45-$ $\mu \mathrm{m}$ syringe filters and directly injected through a $20 \mu \mathrm{L}$ fixed loop onto the column.

Method 1. The mobile phase was acetonitrile with 2.0\% acetic acid (solvent A) and Milli-Q water with $2.0 \%$ acetic acid (solvent B) in gradient mode, with the flow rate $1.0 \mathrm{~mL} / \mathrm{min}$ on ZORBAX SB-Aq column. The gradient was as follows: $92 \% \mathrm{~A}$ at $0 \mathrm{~min}, 80 \% \mathrm{~A}$ at $18 \mathrm{~min}, 60 \%$ $\mathrm{A}$ at $25 \mathrm{~min}, 55 \% \mathrm{~A}$ at $30 \mathrm{~min}, 35 \% \mathrm{~A}$ at $40 \mathrm{~min}, 20 \% \mathrm{~A}$ at $50 \mathrm{~min}$, constant $20 \% \mathrm{~A}$ for $4 \mathrm{~min}$, $90 \%$ A at 57 min following 3 min constant $90 \%$ A. Stop time was $2 \mathrm{~min}$.

Method 2. The mobile phase was acetonitrile : methanol (solvent A) and Milli-Q water with $2.0 \%$ acetic acid (solvent $\mathrm{B}$ ) in gradient mode, with the flow rate $1.0 \mathrm{~mL} / \mathrm{min}$ on ZORBAX SBC18 column. The gradient was as follows: $95 \% \mathrm{~B}$ at $0 \mathrm{~min}, 85 \% \mathrm{~B}$ at $15 \mathrm{~min}, 35 \% \mathrm{~B}$ at $45 \mathrm{~min}$, $5 \% \mathrm{~B}$ at $60 \mathrm{~min}, 95 \% \mathrm{~B}$ at $63 \mathrm{~min}$. Stop time was $2 \mathrm{~min}$. 
Ferulic acid, trans-cinnamic acid, 2-hydroxycinamic acid, gallic acid, caffeic acid, $p$ coumaric acid, chlorogenic acid, quercetin and kaempferol were detected by method 1, while $(+)$-catechin hydrate, cyanin chloride, idaenin chloride, callistephin chloride and kuromanin chloride were detected by method 2 .

\section{Validation parameters}

The detector linearity response was checked by preparing the blank plant sample according to the Generalić et al. [15] method and after the extraction the residue was diluted in $1.5 \mathrm{~mL}$ of the phenol acids and flavonoids mixture standard in mass concentrations of 1.0, 2.0, 5.0, 10.0, 50.0, 100,200 and $250 \mu \mathrm{g} / \mathrm{mL}$. The reproducibility of the method was determined by analyzing the sample of the same mass concentration level $(10.0 \mu \mathrm{g} / \mathrm{mL} / \mathrm{kg})$ in six replicates and shown through the relative standard deviation - RSD (\%). The limits of quantification (LOQ) were determined by adding $100 \mu \mathrm{L}$ of phenols and flavonoids mixture standard to the concentration of $1.0 \mu \mathrm{g} / \mathrm{mL}$, in $0.5 \mathrm{~g}$ of the sample in six replicates.

\section{Seedling growth}

The experiment was performed at the Laboratory of Biochemistry, Faculty of Agriculture, Novi Sad and conducted under controlled conditions $\left(28{ }^{\circ} \mathrm{C}, 60 \%\right.$ relative humidity, a photoperiod of $18 \mathrm{~h}$, and a light intensity of $10.000 \mathrm{~lx}$ ). The black nightshade, Solanum nigrum L., and pepper, Capsicum annuum L., seeds were surface-sterilized with $3 \% \mathrm{H}_{2} \mathrm{O}_{2}(\mathrm{v} / \mathrm{v})$ and washed with sterilized deionised water. These seeds were placed in plastic pots containing sterile sand and were maintained under dark conditions. Thirty-day-old seedlings were transplanted in plastic pots containing $700 \mathrm{~mL}$ of Hoagland's solution $\left(10 \% \mathrm{MgSO}_{4} \times 7 \mathrm{H}_{2} \mathrm{O}, 10 \% \mathrm{Ca}\left(\mathrm{NO}_{3}\right)_{2} \times 4 \mathrm{H}_{2} \mathrm{O}\right.$, $10 \% \mathrm{KH}_{2} \mathrm{PO}_{4}, 10 \% \mathrm{KNO}_{3}$, microelements, $7.5 \% \mathrm{Fe}$-EDTA), and 7 and $14 \mathrm{~mL}$ of $C$. menthifolium aqueous extract, while pots of control contained the same volume of nutrient solution. Seedlings were harvested for determining the investigated biochemical parameters 24 , 72 and $120 \mathrm{~h}$ after the treatments with the $C$. menthifolium aqueous extract.

\section{Analysis of the antioxidant enzymes SOD, CAT and POD}

For the determination of the oxidative stress parameters, $2 \mathrm{~g}$ of fresh plant material (leaves and roots from each growth condition: control, 0.1 and $0.2 \%$ C. menthifolium aqueous extract) was homogenized in $10 \mathrm{~mL}$ of phosphate buffer $(0.1 \mathrm{M}, \mathrm{pH} 7.0)$ prepared in-house. After centrifugation, supernatants were used for protein quantification and enzyme activity assays. Biochemical analyses were carried out spectrophotometrically using an UV/VIS spectrophotometer (Thermo Scientific Evolution 220 (USA)).

Measurement of protein levels in the supernatants was performed according to the method of Bradford [16, 17]. Catalase (CAT) (EC 1.11.1.6) activity was determined according to Sathya and Bjorn [18]. The decomposition of $\mathrm{H}_{2} \mathrm{O}_{2}$ was followed as a decrease in absorbance at 240 $\mathrm{nm}$. The enzyme extract $(20 \mu \mathrm{L}$ extract of leaves or $0.1 \mathrm{~mL}$ extract of roots, separately) was added to the assay mixture containing $1 \mathrm{~mL}$ for leaves and $1.5 \mathrm{~mL}$ for roots of $50 \mathrm{mM}$ potassium phosphate buffer ( $\mathrm{pH}$ 7.0) prepared in-house and $10 \mathrm{mM} \mathrm{H}_{2} \mathrm{O}_{2}$. The activity of the enzyme was expressed in U/mg of protein. Superoxide dismutase (SOD) (EC 1.15.1.1) activity was assayed according to the method of Mandal et al. slightly modified by measuring its ability to inhibit photochemical reduction of nitro blue tetrazolium (NBT) chloride [19]. The reaction mixture contained $50 \mathrm{mM}$ phosphate buffer ( $\mathrm{pH} 7.8$ ), $13 \mathrm{mM}$ L-methionine, $75 \mu \mathrm{M}$ NBT, 0.1 mM EDTA, $2 \mu \mathrm{M}$ riboflavin and $20 \mu \mathrm{L}$ of the enzyme extract. It was kept under a fluorescent lamp for $30 \mathrm{~min}$, and the absorbance was read at $560 \mathrm{~nm}$. One unit of the SOD activity was defined as the amount of enzymes required to inhibit reduction of NBT by $50 \%$. The activity of 
the enzyme was expressed in U/mg of protein. Peroxidase (POD) (EC 1.11.1.7) activity was measured using guaiacol and pyrogallolas substrates according to Morkunas and Gmerek [20].

Pyrogallol peroxidase activity. This method is based on the measurement of the content of purpurogallin - a product of pyrogallol oxidation. The enzyme extract $(20 \mu \mathrm{L})$ was added to the assay mixture containing $3 \mathrm{~mL}$ of $180 \mathrm{mM}$ pyrogallol and $20 \mu \mathrm{L}$ of $2 \mathrm{mM} \mathrm{H}_{2} \mathrm{O}_{2}$. The absorbance was recorded at $430 \mathrm{~nm}$.

Guaiacol peroxidase activity. This method consists of an assay of tetraguaiacol - a colored product of guaiacol oxidation in the investigated sample. The enzyme extract $(40 \mu \mathrm{L})$ was added to the assay mixture containing $3 \mathrm{~mL}$ of $20 \mu \mathrm{M}$ guaiacol and $20 \mu \mathrm{L}$ of $3 \mathrm{mM} \mathrm{H}_{2} \mathrm{O}_{2}$. The absorbance was recorded at $436 \mathrm{~nm}$. The activity of the enzyme was expressed in U/mg of protein.

Lipid peroxidation. Lipid peroxidation was measured at $532 \mathrm{~nm}$ using the thiobarbituric acid (TBA) test [19]. The enzyme extract $(0.5 \mathrm{~mL})$ was incubated with $2 \mathrm{~mL}$ of $20 \%$ trichloroacetic acid (TCA) containing $0.5 \%$ thiobarbituric acid for $40 \mathrm{~min}$ at $95{ }^{\circ} \mathrm{C}$. The reaction was stopped by cooling on ice for $10 \mathrm{~min}$ and the product was centrifuged at $10.000 \times \mathrm{g}$ for $15 \mathrm{~min}$. The total amount of TBA-reactive substances was given innmolof malondialdehyde (MDA) equivalents per $\mathrm{mg}$ of proteins.

Insects

The insects used in the experiment, adults of whitefly Trialeurodes vaporariorum (Westwood, 1856) (Homoptera: Aleyrodidae), were collected in the greenhouse where it had been developed on peppers and tomatoes. The experiment was carried out at the Faculty of Agriculture, University of Novi Sad.

Bioassays

The bioassays were carried out using groups of 20 adults of $T$. vaporariorum, keptin round, transparent laboratory dishes (height: $25 \mathrm{~cm}$ and diameter: $12 \mathrm{~cm}$ ), and fed on the pepper nursery plants containing a known concentration $(0.1 \%)$ of the C. menthifolium aqueous extract. The aqueous extract was applied together with adjuvant, in an amount of $20 \mathrm{~mL}$ per plant with hand sprayer, for better adhesion to the leaf surface. Pepper plants with water, adjuvant and 20 insects were used as controls. Aqueous extract plus adjuvant and water plus adjuvant were applied on plants by spraying, after that, insects (20 individuals for each plant) were set up on the plants in laboratory dishes. The experiment was set in three replicates and control. A no-choice method in which control and treated plants were placed individually in each dish, was adopted in this experiment.Mortality was checked after 24, 48 and $96 \mathrm{~h}$.

\section{Statistical analysis}

All measurements were performed in triplicates. Values of the biochemical parameters were expressed as mean \pm standard error of mean and tested by ANOVA followed by comparison of the means by Duncan's multiple range test $(\mathrm{p}<0.05)$. Data were analyzed using STATISTICA for Windows version 11.0. Comparable percentage was done by the formula: $\Delta(\%)=(100 \times$ sample / control $)-100$. 


\section{RESULTS AND DISCUSSION}

\section{Determination of phenolic compounds}

Plant phenolic compounds and their protective role against oxidative damage caused diseases have been the subject of a great number of different studies. However, they are also involved in plant allelopathy and have substantial allelopathic application as herbicides, insecticides, and fungicides [21]. The total amount of phenols in C. menthifolium aqueous extract was $104 \pm 5.0$ $\mathrm{mg} \mathrm{GAE} / \mathrm{g}$ of DW. The total flavonoids content was $7.0 \pm 0.1 \mathrm{mg}$ rutin/g of DW. HPLC-DAD chromatogram of phenol acids standard and C. menthifolium extract are shown in Figure 1 . The method was evaluated in terms of linearity, reproducibility and limits of quantification. All the validation parameters are shown in Table 1 . Compounds identified and quantified in the aqueous extract of $C$. menthifolium are shown in Table 2. The main constituent of phenol components was gallic acid $(15.9 \pm 0.7 \mu \mathrm{g} / \mathrm{g})$. Caffeic acid and 2-hydroxy-cinnamic acid were present at a concentration of $13.9 \pm 0.7$ and $13.5 \pm 0.5 \mu \mathrm{g} / \mathrm{g}$, respectively.

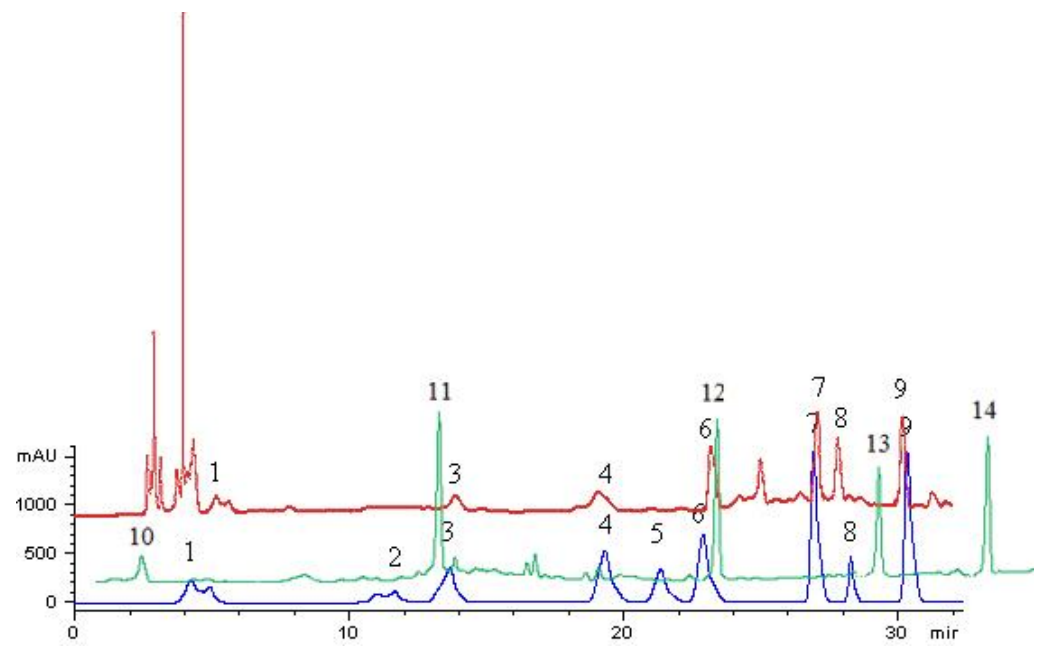

Figure 1. HPLC-DAD chromatogram of phenol acids standard (blue line: method 1: 1 - gallic acid, 2 - chlorogenic acid, 3 - caffeic acid, 4 - p-coumaric acid, 5 - ferulic acid, 6 - 2hydroxy cinamic acid, 7 - trans cinnamic acid, 8 - quercetin, 9 - kaempferol; green line: method 2: 10 - (+)-catechin hydrate, 11 - kuromanin chloride, 12 - cyanin chloride, 13 - idaenin chloride, 14 - callistephin chloride; red line: chromatogram of $C$. menthifolium extract).

Antioxidant enzyme activity and MDA content

The activity of the antioxidant enzymes in leaves and roots of black nightshade was significantly affected by the $C$. menthifolium aqueous extract. In leaves of black nightshade, the significant increase in activity of SOD and CAT was detected in the treatment with both concentrations ofthe C. menthifolium aqueous extract. Activity of CAT showed an increase to $191 \%$ in the treatment with $0.1 \%$ C. menthifolium aqueous extract and an increase to $126 \%$ in the treatment with $0.2 \%$ C. menthifolium aqueous extract, $120 \mathrm{~h}$ after the treatment. Activity of SOD showed an increase to $110 \%$ in the treatment with $0.1 \%$ C. menthifolium aqueous extract $120 \mathrm{~h}$ after the treatment (Table 3$)$. The highest activity of the guaiacol peroxidise (151\% compared to control) was observed in plants $72 \mathrm{~h}$ after the treatment with $0.2 \%$ C. menthifolium aqueous extract. In 
roots of the black nightshade, the activity of CAT was significantly increased $120 \mathrm{~h}$ after the treatments with both concentrations of the C. menthifolium aqueous extract $(238 \%$ after the treatment with $0.1 \%$ extract).Higher tested concentration of $C$. menthifolium aqueous extract $(0.2 \%)$ significantly increases the activity of pyrogallol peroxidise $120 \mathrm{~h}$ after the treatment $(54.3 \%)$. Both tested concentrations of the C. menthifolium aqueous extract showed a significant increase in the activity of SOD, CAT and peroxidases of pepper leaves after $120 \mathrm{~h}$ as compared to control (Table 4). In the same time, an increase in peroxidases activity in the root was detected. Some other authors reported changes in antioxidant enzyme activities in plants under oxidative stress [22].

Table 1. Validation parameters for phenolic compounds.

\begin{tabular}{|l|c|c|c|}
\hline Phenolic acid & $\mathrm{R}^{2}$ & Repetability (RSD, \%) & $\mathrm{LOQ}(\mu \mathrm{g} / \mathrm{kg})$ \\
\hline Gallic acid & 0.9979 & 7.4 & 0.3 \\
\hline Ferulic acid & 0.9982 & 1.7 & 0.3 \\
\hline 2-Hydroxy cinamic acid & 0.9995 & 10.6 & 0.3 \\
\hline trans-Cinnamic acid & 0.9997 & 4.2 & 0.3 \\
\hline Caffeic acid & 0.9970 & 13.4 & 0.3 \\
\hline$p$-Coumaric acid & 0.9970 & 8.7 & 0.3 \\
\hline Chlorogenic acid & 0.9982 & 6.5 & 0.3 \\
\hline Quercetin & 0.9950 & 3.2 & 0.3 \\
\hline$(+)$-Catechin hydrate & 0.9979 & 9.5 & 0.3 \\
\hline Cyanin chloride & 0.9982 & 4.3 & 0.3 \\
\hline Idaenin chloride & 0.9995 & 9.2 & 0.3 \\
\hline Callistephin chloride & 0.9991 & 11.7 & 0.3 \\
\hline Kuromanin chloride & 0.9987 & 5.9 & 0.3 \\
\hline Kaempferol & 0.9997 & 12.1 & 0.3 \\
\hline
\end{tabular}

Table 2. Phenolic compounds (mean $\pm \mathrm{SD} \mu \mathrm{g} / \mathrm{g}$ ) presented in the $C$. menthifolium aqueous extract.

\begin{tabular}{|l|l|}
\hline Phenolic compounds & $\mu \mathrm{g} / \mathrm{g}$ \\
\hline Gallic acid & $15.9 \pm 0.7$ \\
\hline Caffeic acid & $13.9 \pm 0.7$ \\
\hline$p$-Coumaric acid & $1.46 \pm 0.1$ \\
\hline 2-Hydroxy cinnamic acid & $13.5 \pm 0.5$ \\
\hline trans-Cinnamic acid & $2.17 \pm 0.1$ \\
\hline Kaempferol & $2.25 \pm 0.2$ \\
\hline Quercetin & $2.39 \pm 0.1$ \\
\hline
\end{tabular}

For various plant species under oxidative stress, a significant increase of lipid peroxidation is observed. The generation of superoxide and hydroxyl radicals was evaluated together with the production of malondialdehyde, the main end product of lipid peroxidation. Thus, malondialdehyde (MDA) content is used as an oxidant biomarker. Statistically significant increases in MDA accumulation were recorded in both black nightshade plant tissues $120 \mathrm{~h}$ after the treatment $(112 \%$ in the leaves and $82.6 \%$ in the roots treated with $0.1 \%$ C. menthifolium aqueous extract) (Table 3). The significant increase in LP intensity in pepper plants was recorded only in roots of pepper plants treated with a higher concentration $(0.2 \%) 120 \mathrm{~h}$ after the treatment $(98.3 \%)$ (Table 4$)$.

The caffeic acid, the second main constituent of phenol components in the C. menthifolium aqueous extract, can stimulate the process of lipid peroxidation inducing oxidative stress in plants. Due to the exposure to caffeic acid, an increase of the lipid peroxidation process was observed in the root of bean [23] and cabbage [24]. In this research, C. menthifolium aqueous extract which contains caffeic acid at a concentration of $13.9 \pm 0.7 \mu \mathrm{g} / \mathrm{g}$, induced lipid peroxidation in black nightshade leaves and roots. 
Our results show that the two tested extract concentrations affected lipid peroxidation in leaves and roots of the black nightshade in the same way, but the highest level of MDA was observed in leaves and roots treated with a lower concentration. The significant higher accumulation of MDA in black nightshade plants treated with the $C$. menthifolium aqueous extract points to the fact that alelopathy-provoked stress was strong enough and the scavenging effects of antioxidant enzymes could not prevent oxidative burst and induction of lipid peroxidation. Siddique and Ismail reported that accumulation of $\mathrm{H}_{2} \mathrm{O}_{2}$ in leaves of race plants in response to $F$. miliacea treatment enhances lipid peroxidation and causes severe oxidative stress $[22]$.

Table 3. The effect of two concentrations $(0.1$ and $0.2 \%)$ of the $C$. menthifolium aqueous extracts on the activities of the antioxidant enzymes (U/mg protein) and on MDA content ( $\mathrm{nmol} / \mathrm{mg}$ protein) in leaves and roots of the black nightshade seedlings compared to control group.

\begin{tabular}{|c|c|c|c|c|}
\hline \multicolumn{2}{|l|}{ Time } & $24 \mathrm{~h}$ & $72 \mathrm{~h}$ & $120 \mathrm{~h}$ \\
\hline \multicolumn{5}{|l|}{ Leaves } \\
\hline \multirow[t]{3}{*}{ Catalase } & Control & $10.3 \pm 0.1^{\mathrm{a}}$ & $25.8 \pm 1.8^{\mathrm{c}}$ & $15.3 \pm 0.1^{\mathrm{b}}$ \\
\hline & $0.1 \%$ & $24.0 \pm 1.7^{\mathrm{c}}$ & $30.7 \pm 1.0^{\mathrm{d}}$ & $44.5 \pm 0.2^{\mathrm{e}}$ \\
\hline & $0.2 \%$ & $15.0 \pm 0.9^{b}$ & $31.8 \pm 2.2^{\mathrm{d}}$ & $34.4 \pm 1.1^{\mathrm{d}}$ \\
\hline \multirow[t]{3}{*}{ Superoxide dismutase } & Control & $16.5 \pm 0.0^{\mathrm{a}}$ & $16.3 \pm 0.2^{\mathrm{a}}$ & $9.88 \pm 0.1^{f}$ \\
\hline & $0.1 \%$ & $24.9 \pm 0.3^{\mathrm{h}}$ & $18.5 \pm 0.4^{b}$ & $20.7 \pm 0.3^{\mathrm{d}}$ \\
\hline & $0.2 \%$ & $22.2 \pm 0.1^{\mathrm{e}}$ & $23.3 \pm 0.4^{\mathrm{g}}$ & $14.8 \pm 0.2^{\mathrm{c}}$ \\
\hline \multirow[t]{3}{*}{ Guaiacol peroxidase } & Control & $(0.95 \pm 0.0)^{\cdot} 10^{2 \mathrm{a}, \mathrm{b}}$ & $(0.94 \pm 0.1)^{\cdot} 10^{2 \mathrm{a}}$ & $(0.84 \pm 0.1)^{\cdot} 10^{2 \mathrm{a}}$ \\
\hline & $0.1 \%$ & $(1.42 \pm 0.1) \cdot 10^{2 \mathrm{c}}$ & $(1.21 \pm 0.1)^{\cdot} 10^{2 b}$ & $(1.94 \pm 0.1)^{\cdot} 10^{2 \mathrm{~d}}$ \\
\hline & $0.2 \%$ & $(1.72 \pm 0.0)^{\cdot} 10^{2 \mathrm{~d}}$ & $(2.36 \pm 0.1)^{\cdot} 10^{2 \mathrm{e}}$ & $(1.06 \pm 0.1)^{\cdot} 10^{2 \mathrm{a}, \mathrm{b}}$ \\
\hline \multirow[t]{3}{*}{ Pyrogallol peroxidase } & Control & $(1.47 \pm 0.0)^{\cdot} 10^{2 \mathrm{a}}$ & $(1.69 \pm 0.1)^{\cdot} 10^{2 \mathrm{a}}$ & $(1.09 \pm 0.0)^{\cdot} 10^{2 b}$ \\
\hline & $0.1 \%$ & $(3.05 \pm 0.1)^{\cdot} 10^{2 f}$ & $(2.24 \pm 0.1)^{\cdot} 10^{2 \mathrm{c}}$ & $(3.45 \pm 0.1)^{\cdot} 10^{2 \mathrm{~g}}$ \\
\hline & $0.2 \%$ & $(2.77 \pm 0.0)^{\cdot} 10^{2 \mathrm{e}}$ & $(2.50 \pm 0.1)^{\cdot} 10^{2 \mathrm{~d}}$ & $(1.57 \pm 0.0)^{\cdot} 10^{2 \mathrm{a}}$ \\
\hline \multirow[t]{3}{*}{ MDA content } & Control & $1.66 \pm 0.0^{\mathrm{a}}$ & $2.15 \pm 0.1^{\mathrm{b}}$ & $1.98 \pm 0.1^{\mathrm{b}}$ \\
\hline & $0.1 \%$ & $2.63 \pm 0.1^{\mathrm{c}}$ & $2.79 \pm 0.1^{\mathrm{c}}$ & $4.19 \pm 0.1^{\mathrm{f}}$ \\
\hline & $0.2 \%$ & $3.00 \pm 0.0^{\mathrm{d}}$ & $3.28 \pm 0.1^{\mathrm{e}}$ & $2.66 \pm 0.0^{\mathrm{c}}$ \\
\hline \multicolumn{5}{|l|}{ Roots } \\
\hline \multirow[t]{3}{*}{ Catalase } & Control & $3.61 \pm 0.1^{\mathrm{a}}$ & $20.1 \pm 0.6^{\mathrm{d}}$ & $9.36 \pm 0.3^{b}$ \\
\hline & $0.1 \%$ & $15.2 \pm 0.1^{\mathrm{c}}$ & $18.9 \pm 1.5^{\mathrm{d}}$ & $31.6 \pm 4.7^{\mathrm{e}}$ \\
\hline & $0.2 \%$ & $11.4 \pm 0.2^{\mathrm{b}, \mathrm{c}}$ & $12.5 \pm 0.6^{\mathrm{b}, \mathrm{c}}$ & $18.7 \pm 1.2^{\mathrm{d}}$ \\
\hline \multirow[t]{3}{*}{ Superoxide dismutase } & Control & $33.9 \pm 0.1^{\mathrm{a}}$ & $25.9 \pm 1.9^{\mathrm{b}}$ & $11.4 \pm 0.7^{\mathrm{f}}$ \\
\hline & $0.1 \%$ & $23.6 \pm 0.8^{b, c}$ & $51.7 \pm 0.4^{\mathrm{d}}$ & $21.7 \pm 1.0^{\mathrm{c}}$ \\
\hline & $0.2 \%$ & $28.4 \pm 0.3^{\mathrm{b}}$ & $10.2 \pm 0.7^{\mathrm{f}}$ & $15.0 \pm 0.8^{\mathrm{e}}$ \\
\hline \multirow[t]{3}{*}{ Guaiacol peroxidase } & Control & $(1.37 \pm 0.1)^{\cdot} 10^{3 \mathrm{a}}$ & $(1.40 \pm 0.1)^{\cdot} 10^{3 \mathrm{a}}$ & $(1.91 \pm 0.1)^{\cdot} 10^{3 b}$ \\
\hline & $0.1 \%$ & $(1.49 \pm 0.1)^{\cdot} 10^{3 \mathrm{a}, \mathrm{b}}$ & $(1.95 \pm 0.1)^{\cdot} 10^{3 \mathrm{c}}$ & $(1.03 \pm .0 .0)^{\cdot} 10^{3 \mathrm{~d}}$ \\
\hline & $0.2 \%$ & $(1.57 \pm 0.0)^{\cdot} 10^{3 \mathrm{a}, \mathrm{b}}$ & $(1.63 \pm 0.5)^{\cdot} 10^{3 \mathrm{a}, \mathrm{b}, \mathrm{c}}$ & $(1.79 \pm 0.1)^{\cdot} 10^{3 \mathrm{~b}, \mathrm{c}}$ \\
\hline \multirow[t]{3}{*}{ Pyrogallol peroxidase } & Control & $(1.30 \pm 0.0) \cdot 10^{3 \mathrm{a}}$ & $(1.34 \pm 0.0)^{\cdot} 10^{3 \mathrm{a}}$ & $(1.33 \pm 0.0)^{\cdot} 10^{3 \mathrm{a}}$ \\
\hline & $0.1 \%$ & $(1.40 \pm 0.0)^{\cdot} 10^{3 \mathrm{a}}$ & $(1.95 \pm 0.0)^{\cdot} 10^{3 \mathrm{~b}}$ & $(1.35 \pm 0.1)^{\cdot} 10^{3 \mathrm{a}}$ \\
\hline & $0.2 \%$ & $(1.43 \pm 0.1)^{\cdot} 10^{3 \mathrm{a}}$ & $(1.40 \pm 0.1)^{\cdot} \cdot 10^{3 \mathrm{a}}$ & $(2.05 \pm 0.1)^{\cdot} 10^{3 \mathrm{~b}}$ \\
\hline \multirow[t]{3}{*}{ MDA content } & Control & $2.38 \pm 0.1^{\mathrm{a}}$ & $3.37 \pm 0.1^{\mathrm{d}}$ & $1.84 \pm 0.0^{\mathrm{b}}$ \\
\hline & $0.1 \%$ & $2.48 \pm 0.1^{\mathrm{a}}$ & $3.87 \pm 0.1^{\mathrm{e}}$ & $3.36 \pm 0.1^{\mathrm{d}}$ \\
\hline & $0.2 \%$ & $3.98 \pm 0.1^{\mathrm{c}}$ & $2.54 \pm 0.1^{\mathrm{a}}$ & $2.93 \pm 0.1^{\mathrm{c}}$ \\
\hline
\end{tabular}

The data are mean values \pm standard error. ${ }^{\text {a-h }}$ values without the same superscripts within each column differ significantly $(p<0.05)$.

Our results reveal that the lower concentration of $C$. menthifolium aqueous extract stimulatesa significant increase in the activity of SOD, CAT and peroxidases of pepper leaves after $120 \mathrm{~h}$ as compared to control. Concurrently, a decrease in accumulation of MDA was recorded. The increased activity of antioxidant enzymes in leaves of treated pepper plants suggests that the defensive system of the plants prevailed and that the lower tested concentration 
of $C$. menthifolium aqueous extract has low allelopathic potential on the pepper antioxidant properties. On the other hand, the significant increase in lipid peroxidation intensity was recorded in leaves and roots of pepper plants treated with the higher concentration $(0.2 \%) 120 \mathrm{~h}$ after the treatment. Our results show that the sensitivity of plants is dependent on the concentration of applied extracts. Furthermore, allelochemicals that inhibit the growth of one plant might stimulate the growth of the same or another plant at different concentrations [5]. In this research, leaves and roots of black nightshade were more affected bythe lower concentration $(0.1 \%)$ of the C. menthifolium aqueous extract than leaves and roots of pepper seedlings. It is a useful finding that there is a concentration of $C$. menthifolium aqueous extract with low allelopathic potential on the pepper antioxidant properties as compared to black nightshade antioxidant properties.

Table 4. The effect of two concentrations ( 0.1 and $0.2 \%)$ of the $C$. menthifolium aqueous extracts on the activities of the antioxidant enzymes ( $\mathrm{U} / \mathrm{mg}$ protein) and on MDA content ( $\mathrm{nmol} / \mathrm{mg}$ protein) in leaves and roots of the pepper seedlings compared to control group.

\begin{tabular}{|c|c|c|c|c|}
\hline \multicolumn{2}{|l|}{ Time } & $24 \mathrm{~h}$ & $72 \mathrm{~h}$ & $120 \mathrm{~h}$ \\
\hline \multicolumn{5}{|l|}{ Leaves } \\
\hline \multirow[t]{3}{*}{ Catalase } & Control & $18.3 \pm 0.5^{\mathrm{a}}$ & $16.8 \pm 0.5^{\mathrm{a}}$ & $17.9 \pm 0.8^{\mathrm{a}}$ \\
\hline & $0.1 \%$ & $22.1 \pm 0.6^{\mathrm{b}}$ & $21.8 \pm 0.8^{\mathrm{b}}$ & $24.0 \pm 1.4^{\mathrm{b}}$ \\
\hline & $0.2 \%$ & $23.4 \pm 0.9^{\mathrm{b}}$ & $16.2 \pm 0.6^{\mathrm{a}}$ & $31.9 \pm 1.5^{\mathrm{c}}$ \\
\hline \multirow[t]{3}{*}{ Superoxide dismutase } & Control & $11.2 \pm 0.1^{\mathrm{a}}$ & $7.42 \pm 0.0^{\mathrm{e}}$ & $5.96 \pm 0.3^{\mathrm{h}}$ \\
\hline & $0.1 \%$ & $9.07 \pm 0.1^{\mathrm{c}}$ & $8.03 \pm 0.1^{\mathrm{d}}$ & $6.21 \pm 0.0^{\mathrm{g}}$ \\
\hline & $0.2 \%$ & $10.2 \pm 0.1^{b}$ & $6.30 \pm 0.1^{f}$ & $9.28 \pm 0.2^{\mathrm{c}}$ \\
\hline \multirow[t]{3}{*}{ Guaiacol peroxidase } & Control & $(5.44 \pm 0.1)^{\cdot} 10^{2 \mathrm{a}}$ & $(4.86 \pm 0.2)^{\cdot} 10^{2 b}$ & $(5.53 \pm 0.2)^{\cdot} 10^{2 \mathrm{a}}$ \\
\hline & $0.1 \%$ & $(3.71 \pm 0.2) \cdot 10^{2 \mathrm{~d}}$ & $(3.25 \pm 0.1) \cdot 10^{2 \mathrm{~d}}$ & $(6.08 \pm 0.1) \cdot 10^{2 \mathrm{c}}$ \\
\hline & $0.2 \%$ & $(2.65 \pm 0.2) \cdot 10^{2 \mathrm{f}}$ & $(5.37 \pm 0.3)^{\cdot} 10^{2 \mathrm{a}}$ & $(7.60 \pm 0.1)^{\cdot} 10^{2 \mathrm{e}}$ \\
\hline \multirow[t]{3}{*}{ Pyrogallol peroxidase } & Control & $(5.86 \pm 0.1)^{\cdot} 10^{2 \mathrm{a}}$ & $(7.07 \pm 0.2)^{\cdot} 10^{2 \mathrm{c}}$ & $(7.83 \pm 0.1) \cdot 10^{2 \mathrm{~d}}$ \\
\hline & $0.1 \%$ & $(4.91 \pm 0.0)^{\cdot} 10^{2 b}$ & $(5.63 \pm 0.3) \cdot 10^{2 \mathrm{a}}$ & $(8.83 \pm 0.1) \cdot 10^{2 \mathrm{e}}$ \\
\hline & $0.2 \%$ & $(4.64 \pm 0.1)^{\cdot} 10^{2 b}$ & $(7.97 \pm 0.2)^{\cdot} 10^{2 \mathrm{~d}}$ & $(9.83 \pm 0.1) \cdot 10^{2 f}$ \\
\hline \multirow[t]{3}{*}{ MDA content } & Control & $2.56 \pm 0.1^{\mathrm{a}}$ & $3.02 \pm 0.1^{\mathrm{b}, \mathrm{c}}$ & $3.29 \pm 0.1^{\mathrm{c}}$ \\
\hline & $0.1 \%$ & $2.96 \pm 0.2^{b}$ & $2.83 \pm 0.0^{\mathrm{a}, \mathrm{b}}$ & $3.01 \pm 0.1^{\mathrm{b}, \mathrm{c}}$ \\
\hline & $0.2 \%$ & $2.52 \pm 0.1^{\mathrm{a}}$ & $3.95 \pm 0.1^{\mathrm{d}}$ & $3.90 \pm 0.2^{\mathrm{d}}$ \\
\hline \multicolumn{5}{|l|}{ Roots } \\
\hline \multirow[t]{3}{*}{ Catalase } & Control & $22.9 \pm 0.7^{\mathrm{a}}$ & $20.4 \pm 0.7^{\mathrm{b}}$ & $10.6 \pm 0.2^{\mathrm{e}}$ \\
\hline & $0.1 \%$ & $18.3 \pm 0.4^{\mathrm{b}, \mathrm{c}}$ & $18.3 \pm 0.8^{\mathrm{c}, \mathrm{b}}$ & $22.4 \pm 0.8^{\mathrm{a}, \mathrm{b}}$ \\
\hline & $0.2 \%$ & $17.3 \pm 1.3^{\mathrm{c}}$ & $12.2 \pm 0.7^{\mathrm{e}}$ & $14.8 \pm 0.5^{\mathrm{d}}$ \\
\hline \multirow[t]{3}{*}{ Superoxide dismutase } & Control & $7.27 \pm 0.1^{\mathrm{a}}$ & $7.99 \pm 0.1^{b}$ & $9.34 \pm 0.2^{\mathrm{e}}$ \\
\hline & $0.1 \%$ & $5.05 \pm 0.2^{\mathrm{c}}$ & $13.2 \pm 0.0^{\mathrm{h}}$ & $10.6 \pm 0.0^{\mathrm{g}}$ \\
\hline & $0.2 \%$ & $8.31 \pm 0.2^{\mathrm{b}}$ & $9.92 \pm 0.1^{f}$ & $3.25 \pm 0.1^{\mathrm{d}}$ \\
\hline \multirow[t]{3}{*}{ Guaiacol peroxidase } & Control & $(3.24 \pm 0.3) \cdot 10^{3 \mathrm{a}}$ & $(3.58 \pm 0.1) \cdot 10^{3} \mathrm{a}, \mathrm{b}$ & $(3.34 \pm 0.1) \cdot 10^{3} \mathrm{a}, \mathrm{b}$ \\
\hline & $0.1 \%$ & $(3.77 \pm 0.1)^{\prime} 10^{3 \mathrm{~b}}$ & $(3.16 \pm 0.1) \cdot 10^{3} \mathrm{a,c}$ & $(4.34 \pm 0.1)^{\cdot} 10^{3 \mathrm{e}}$ \\
\hline & $0.2 \%$ & $(2.12 \pm 0.1) \cdot 10^{3 \mathrm{~d}}$ & $(2.80 \pm 0.1)^{\cdot} 10^{3 \mathrm{c}}$ & $(3.67 \pm 0.1) \cdot 10^{3 \mathrm{a}, \mathrm{b}}$ \\
\hline \multirow[t]{3}{*}{ Pyrogallol peroxidase } & Control & $(2.62 \pm 0.0)^{\cdot} 10^{3 \mathrm{a}}$ & $(2.47 \pm 0.1) \cdot 10^{3} \mathrm{a}, \mathrm{b}$ & $(1.95 \pm 0.1) \cdot 10^{3 \mathrm{~d}}$ \\
\hline & $0.1 \%$ & $(2.37 \pm 0.1)^{\prime} 10^{3 \mathrm{~b}}$ & $(2.24 \pm 0.1) \cdot 10^{3 \mathrm{c}, \mathrm{b}}$ & $(2.06 \pm 0.0) \cdot 10^{3 c, d}$ \\
\hline & $0.2 \%$ & $(1.58 \pm 0.0) \cdot 10^{3 \mathrm{e}}$ & $(1.40 \pm 0.1)^{\cdot} 10^{3 \mathrm{e}}$ & $(2.16 \pm 0.1) \cdot 10^{3 \mathrm{c}}$ \\
\hline \multirow[t]{3}{*}{ MDA content } & Control & $2.50 \pm 0.1^{\mathrm{a}, \mathrm{b}}$ & $2.96 \pm 0.1^{\mathrm{c}, \mathrm{b}}$ & $2.38 \pm 0.1^{\mathrm{a}}$ \\
\hline & $0.1 \%$ & $3.88 \pm 0.2^{\mathrm{d}}$ & $3.13 \pm 0.2^{\mathrm{c}}$ & $2.87 \pm 0.1^{\mathrm{b}}$ \\
\hline & $0.2 \%$ & $2.45 \pm 0.1^{\mathrm{a}, \mathrm{b}}$ & $4.17 \pm 0.1^{\mathrm{d}}$ & $4.72 \pm 0.1^{\mathrm{e}}$ \\
\hline
\end{tabular}

The data are mean values \pm standard error. ${ }^{\text {a-h }}$ values without the same superscripts within each column differ significantly $(p<0.05)$.

The allelopathic effects of plants of the family Lamiaceae were investigated in a number of studies. Safari et al. found that aqueous extracts of Thymus kotschyanus (Lamiaceae) exhibited dose-dependent allelopathic effects on Bromus tomentellus seed germination and seedling 
growth [25]. Bajalan et al. examined the effect of different concentrations of the aqueous extract of Salvia officinalis (Lamiaceae) on the germination of Amaranthus retroflexus and found that the extract had shown a strong inhibitory effect on seed germination [26].

\section{The mortality of $T$. vaporariorum}

The greenhouse whitefly is an important pest especially in vegetable and ornamental crops [27]. They suck sap, causing the plants to become weak and susceptible to attack by diseases. The biggest problem in combating the whitefly life cycle of this insect and the interweaving generation is that all forms of development can be found on one sheet. Control of the greenhouse whitefly is difficult because of a high resistance against commonly used insecticides [28]. Some plant-derived compounds can be highly effective against the insecticide-resistant insect pest [29]. It has been shown that the caffeic acid possesses insecticidal activity [30]. In our previous study we have reported that the aqueous extracts of some Lamiaceae species, which contain caffeic acid in high amount, exhibited a toxic effect against the greenhouse whitefly with a high mortality rate $[31,32]$. In the present work, the aqueous extract of $C$. menthifolium was evaluated on the greenhouse whitefly. After 24 and $48 \mathrm{~h}$ of exposure, the mortality of $T$. vaporariorum was low. The mortality rate reached $50 \%$ after $96 \mathrm{~h}$ of exposure (Figure 2). Results of other authors indicate a potential use of plant extracts in pest management of whiteflies. Cruz-Estrada et al. reported that ethanolic extracts of P. Alliaceae and T. arborea leaves showed very high insecticidal effects on eggs and the nymphs whitefly (Bemisia tabaci Genn.) [33].

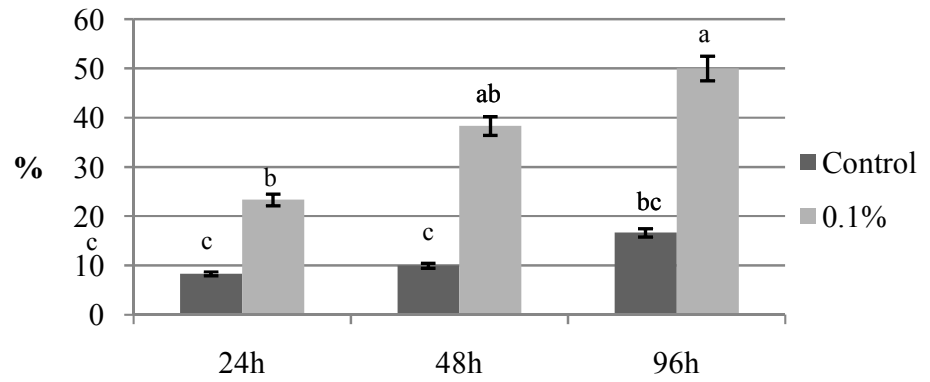

Figure 2 . The mortality of $T$. vaporariorum adult fed for 4 days with formulation containing a known concentration $(0.1 \%)$ of $C$. menthifolium aqueous extract.

\section{CONCLUSION}

In summary, phytotoxic effects of $C$. menthifolium aqueous extracts were different between the two studied plants, the black nightshade seedlings were more sensitive than pepper seedlings, which points to the different responses of species when facing allelochemicals. The allelopathic potential of the $C$. menthifolium aqueous extract on the black nightshade antioxidant properties and the mortality rate of whitefly indicate that the plant extracts and natural substances should be explored in the development of natural pesticides. 


\section{ACKNOWLEDGEMENT}

We thank Branislav Trudić, MSc, plant life scientist and research associate of Institute of Lowland Forestry and Environment, University of Novi Sad, Serbia, for valuable technical comments and suggestions and initial proofreading of the manuscript.

\section{REFERENCES}

1. Farooq, M.; Jabran, K.; Cheema, Z.A.; Wahid, A.; Siddique, K.H.M. The role of allelopathy in agricultural pest management. Pest Manag. Sci. 2011, 67, 493-506.

2. Mandal, M.S.; Chakraborty, D.; Dey, S. Phenolic acids act as signaling molecules in plantmicrobe symbioses. Plant Signal. Behav. 2010, 5, 359-368.

3. Gella, D.; Ashagre, H.; Negewo, T. Allelopathic effect of aqueous extracts of major weed species plant parts on germination and growth of wheat. J. Agric. Crop Res. 2013, 1, 30-35.

4. Bhadoria, P.B.S. Allelopathy: A natural way towards weed management. Am. J. Exp. Agric. 2011, 1, 7-20.

5. Naz, R.; Bano, A. Effects of allelochemical extracts from medicinal plants on physiological and biochemical mechanisms of maize (Zea mays L.) seedlings. Int. J. Agron. Agric. Res. 2014, 5, 31-39.

6. Weir, T.L.; Park, S.W.; Vivanco, J.M. Biochemical and physiological mechanisms mediated by allelochemicals. Curr. Opin. Plant Biol. 2004, 7, 472-479.

7. Zeng, R.S.; Mallik, A.U.; Luo, S. Allelopathy in Sustainable Agriculture and Forestry, 1st ed., Springer: New York; 2008; p 63.

8. Bogatek, R.; Gniazdowska, A. ROS and phytohormones in plant-plant allelopathic interaction. Plant Signal. Behav. 2007, 2, 317-318.

9. Soares, C.; De Sousa, A.; Pinto, A.; Azenha, M.; Teixeira, J.; Azevedo, R.A.; Fidalgo, F. Effect of 24-epibrassinolide on ROS content, antioxidant system, lipid peroxidation and $\mathrm{Ni}$ uptake in Solanum nigrum L. under Ni stress. Environ. Exp. Bot. 2016, 122, 115-125.

10. Pietta, P.G. Flavonoids as antioxidants. J. Nat. Prod. 2000, 63, 1035-1042.

11. De Albuquerque, M.B.; Dos Santos, R.C.; Lima, L.M.; Melo Filho, P.A.; Nogueira, R.J.M.C.; Da Camara, C.A.G.; Ramos, A.R. Allelopathy, an alternative tool to improve cropping systems. A review. Agron. Sustain. Dev. 2011, 31, 379-395.

12. Mandal, C.; Ghosh, N.; Adak, M.K.; Dey, N. Interaction of polyamine on oxidative stress induced by exogenously applied hydrogen peroxide in Salvinia natans Linn. Theor. Exp. Plant Physiol. 2013, 25, 203-212.

13. Hagerman, A.; Harvey-Mueller, I.; Makkar, H.P.S. Quantification of Tannins in Tree Foliage - A Laboratory Manual, FAO/IAEA: Vienna; Austria; 2000; p 4.

14. Dey, P.M.; Harborne, J.B. Methods in Plant Biochemistry, 1st ed., Marcel Dekker: New York; 1989; p 197.

15. Generalić, I.; Skroza, D.; Šurjak, J.; Možina, S.; Ljubenkov, I.; Katalinić, A.; Šimat, V.; Katalinić, V. Seasonal variations of phenolic compounds and biological properties in sage (Salvia officinalis L.). Chem. Biodivers. 2012, 9, 441-457.

16. Sedmark, J.; Grossberg, S.E. A rapid, sensitive and versatile assay for protein using Coomassie Brilliant Blue G250. Anal. Biochem. 1977, 79, 544-552

17. Spector, T. Refinement of the Coomassie blue method of protein quantitation. Anal. Biochem. 1978, 86, 142-146.

18. Sathya, E.; Bjorn, M.E. Plant Stress Tolerance, Humana Press: Oklahoma; USA; 2010; pp 273-280.

19. Mandal, S.; Mitra, A.; Mallick, N. Biochemical characterization of oxidative burst during interaction between Solanum lycopersicum and Fusarium oxysporum f. sp. lycopersici. Physiol. Mol. Plant Pathol. 2008, 72, 56-61. 
20. Morkunas, I.; Gmerek, J. The possible involvement of peroxidase in defense of yellow lupine embryo axes against Fusarium oxysporum. J. Plant Physiol. 2007, 164, 185-194.

21. Li, Z.H.; Wang, Q.; Ruan, X.; Pan, C.D.; Jiang, D.A. Phenolics and plant allelopathy. Molecules 2010, 15, 8933-8952.

22. Siddique, M.A.B.; Ismail, B.S. Allelopathic effects of Fimbristylis miliacea on the physiological activities of five Malaysian rice varieties. Aust. J. Crop Sci. 2013, 7, 20622067.

23. Singh, H.P.; Kaur, S.; Batish, D.R.; Kohli, R.K. Caffeic acid inhibits in vitro rooting in mung bean [Vigna radiata (L.) Wilczek] hypocotyls by inducing oxidative stress. Plant Growth Regul. 2009, 57, 21-30.

24. Singh, N.B.; Sunaina Yadav, K.; Amist, N. Phytotoxic effects of cinnamic acid on cabbage (Brassica oleracea var. capitata). J. Stress Physiol. Biochem. 2013, 9, 307-317.

25. Safari, H.; Tavili, A.; Saberi, M. Allelopathic effects of Thymus kotschyanus on seed germination and initial growth of Bromus tomentellus and Trifolium repens. Front. Agric. China 2010, 4, 475-480.

26. Bajalan, I.; Oregani, K.E.; Moezi, A.A.; Gholami, A. Allelopathic effects of aqueous extract from Salvia officinalis L. on seed germination of wheat and velvet flower. T. J. E. A. S. 2013, 3, 485-488.

27. Manzano, M.R.; Lenteren, J.C. Life history parameters of Trialeurodes vaporariorum (Westwood) (Hemiptera: Aleyrodidae) at different environmental conditions on two bean cultivars. Neotrop. Entomol. 2009, 38, 452-458.

28. Liang, P.; Cui, J.Z.; Yang, X.Q.; Gao, X.W. Effects of host plants on insecticide susceptibility and carboxylesterase activity in Bemisia tabaci biotype B and greenhouse whitefly, Trialeurodes vaporariorum. Pest Manag. Sci. 2007, 63, 365-371.

29. Choi, W.I.; Lee, E.H.; Choi, B.R.; Park, H.M.; Ahn, Y.J. Toxicity of plant essential oils to Trialeurodes vaporariorum (Homoptera: Aleyrodidae). J. Econ. Entomol. 2003, 96, 14791484.

30. Pavela, R.; Vrchotova, N.; Šerá, B. Repellency and toxicity of three impatiens species (Balsaminaceae) extracts on Myzus persicae Sulzer (Homoptera: Aphididae). $J$. Biopesticides 2009, 2, 48-51.

31. Šućur, J.; Popović, A.; Petrović, M.; Anačkov, G.; Kiprovski, B.; Prvulović, D. Alleloppathic effects and insecticidal activity of the aqueous extract of Satureja montana L. J. Serb. Chem. Soc. 2015, 80, 475-484.

32. Šućur, J.; Popović, A.; Petrović, M.; Anačkov, G.; Malenčić, Dj.; Prvulović, D. Allelopathic effects and insecticidal activity of Salvia sclarea L. Studia UBB Chemia 2015, 60, 253-264.

33. Cruz-Estrada, A.; Gamboa-Angulo, M.; Borges-Argáez; Ruiz-Sánchez, E. Insecticidal effects of plant extracts on immature whitefly Bemisia tabaci Genn. (Hemiptera: Aleyroideae). Electron. J. Biotechnol. 2013, 16, 1-9; DOI: 10.2225/vol16-issue1-fulltext-6. 